\title{
Ricardo Rojas y la americanidad
}

66 A poesia en América está en todas partes menos en los versos", sen-

1 tenciaba Alberdi. El modernismo literario europeizante, como lo era el sociólogo de Bases en punto a planes civilizadores, tampoco permaneció impermeable a la influencia telúrica. Dicho movimiento acaudillado por el nicaragüense Rubén Darío, por el argentino Leopoldo Lugones y por el boliviano Ricardo Jaimes Freyre, dio la espalda al neo-clasicismo peninsular. Simultáneamente estableció contactos con el pensamiento y 'el arte del resto de Europa, de cuya contaminación se preservaban las letras españolas como las personas aprensivas que viven en clausura por temor a las corrientes de aire. Rojas, argentino y por añadidura hijo de una provincia mediterránea, militó entre los adeptos del simbolismo francés sin abdicar de su amor a España ni mucho menos de su reencuentro con el rescoldo de la cultura autóctona. Conviene tener en cuenta esta singular posición para seguir el curso de sus fervores juveniles y de su progresivo recogimiento en una devoción más hispano-indigenista que criollista.

Por su parte, el modernismo surgió de este lado del Atlántico como una insurrección en el dominio estético de las minorías finiseculares. "Los países de América se adelantan ahora a España en más de quince años en esta renovación literaria", apunta Pedro Henríquez Ureña. Aquellos jóvenes adalides sentían impaciencia por hombrearse con el nuevo espíritu de Europa que había enviado al Nuevo Mundo conquistadores, aventureros, evangelistas, inquisidores, piratas, invasores de diversas confesiones y banderas. Cierto es que antes de los amagos reaccionarios de la Santa Alianza habían venido del viejo continente, bien que de contrabando, los gérmenes de emancipación con la filosofía de los enciclopedistas; luego se transplantó el romanticismo literario junto con el liberalismo político y económico. 
Los modernistas aspiraban a llevar adelante la liberación en el fuero estético. Hasta donde Rojas los acompañaba lo testimonia su libro La victoria del bombre (1903), promisora muestra poética de los veinte años y luego Los lises del blasón ( I9II), lleno de reminiscencias heráldicas y alardes de técnica que acusan el trasiego de la sensibilidad afrancesada. Sin embargo despuntan en ambos volúmenes auras precursoras del genio nativo. El joven autor, a tono con sus cofrades, ambicionaba a poner las letras locales al día y sincronizarlas con los centros de cultura que marchaban a la vanguardia. El precio pagado consistía primero en absorber una epidemia de "galicismos mentales" y sentimentales en el gusto. La compensación estaba en el rodeo, porque no en balde el espíritu francés es un transmisor casi insustituible de valores universales. Gracias a ellos Rojas sintió aguijoneada la autoconciencia americana, aunque su vía predilecta de expresión, apenas transpuesta la mocedad, antepondría la prosa al virtuosismo de la rima taraceada. Quizás la afición prematura al canto civil preanunciaba su posterior tendencia a descifrar en fragmentos de doctrina los númenes de la patria. Rojas, lejos de renunciar a las inmunidades del vate y del aedo, reservaría el soplo órfico y el lenguaje a ratos sibilino para deletrear la clave de nuestros arquetipos en función del destino nacional y americano. Las interpretaciones históricas del autor de El santo de la espada se resienten de esa propensión al esoterismo donde concurre el ritual de las logias, tan decisivas en la revolución americana. Añádase el hieratismo reencarnado del augur que a partir de la Conquista, vio ponerse el sol en su imperio.

Dentro del modernismo literario coexistían, a comienzos de siglo, varias corrientes. Al flanco de la sugestión cosmopolita y en pugna con su preponderancia, se alzaba el criollismo, beneficiario de las conquistas formales de la nueva estética. Rojas iba a participar del cisma, aunque con un rumbo hacia tradiciones todavía más arraigadas en el Nuevo Mundo. Rufino Blanco Fombona, arbitrario, si bien vocero de la heterodoxia bastante extendida, no veía en Rubén Dario más que elementos exóticos y preciosistas. "Sólo uno de nuestros poetas modernistas, uno de los menos leídos o eruditos -escribía en I93I- antípoda de todo artificialismo, único en esto, como es único en el saber sentir y expresar la naturaleza de América: José Santos Chocano, es de una exuberancia, de una elocuencia profundamente instintivas y raciales". El apasionado escritor venezolano revalida la nueva escuela literaria en la medida que servía al auge del criollismo, vale decir, "la vuelta a la naturaleza, a la sencillez, a la verdad, a la vida, a la América". Rojas no prescindía del criollo, por supuesto, pero car. 
gaba el acento en el desagravio del indio. Tal empaque desusado para la sensibilidad de entonces, estetizante y ávida de refinamientos, provocó resistencias seguidas de impugnaciones. Rojas, colocado en una situación de réprobo para los cultores de la belleza inviolable, no dejó de acusar el impacto. Propenso por naturaleza al retraimiento laborioso, obedeció al reclamo de la vocación cada vez más definida, la cual no sólo lo apartaba de los bullangueros cenáculos casi sin incentivo para él, sino de aquellos sectores del modernismo frivolamente literarios. El autor de $E l$ puis de la selva entroncaba con la línea de intérpretes del hombre y la tierra nativos -Echeverría, Sarmiento, Hernández-, cuyo eslabón más esclarecido e inmediato era Joaquín V. González. Sólo que el vigoroso autor de Mis montañas pertenecía a la generación precedente a la de Rojas, quien, fuera del maestro riojano y Rafael Obligado, su coetáneo, contaba a Martiniano Leguizamón entre los pocos temperamentos afines. De cualquier modo, Rojas puso énfasis y dio jerarquía de convicciones ancestrales a la reiterada reivindicación indigenista. Esta tesis, a despecho de otros factores, si no arrancó de una postura polémica se afianzó por lo menos en el ánimo del autor. Tomó cuerpo impelida por su propia carrera de obstáculos.

\section{NACIONALISMO ARGENTINO Y AMERYCANO}

Ricardo Rojas formuló el primer esbozo de su teoría de la nacionalidad al regreso del viaje a Europa (julio I908) donde cumplió un encargo del gobierno argentino. La misión consistía en recoger antecedentes de los centros del Viejo Mundo especializados en el estudio de la historia. Se trataba de incorporarlos a las escuelas de nuestro país, adaptándolos a sus características y exigencias. Rojas volvió a Buenos Aires con el alma henchida de imágenes. Viajero sensible y culto, no podía menos que rendir tributo ante el espectáculo de hombres, paisajes y tesoros de arte de la civilización inmemorial. Pero el deslumbramiento se tradujo a poco en un revulsivo. Su libro inmediato La restauración nacionalista, saludado por Unamuno y Maeztu, contiene el informe oficial y a la vez una requisitoria contra el cosmopolitismo. Según Alejandro Korn, el autor fijó su posición polémica "no como un retorno al pasado ni como un culto postizo de los próceres, sino como una palingenesia de energías ingénitas e históricas, latentes en las entrañas de nuestro pueblo". Rojas propugna allí la escuela pública encaminada a detener la acción disgregadora que antepone los intereses particulares a los reclamos de la ética solidaria. Impugna los institutos privados porque la discriminación pedagógica trasunta 
la social. Mina el campo de la sensibilidad infantil, pues abre el cauce subjetivo a la noción de privilegio y la adherencia a otras prevenciones. Rojas, partidario de la escuela pública, recomienda la enseñanza modeladora de la historia patria. Encuentra en ella el reactivo indispensable para sacudir la aletargada conciencia de la nacionalidad. El autor de $L a$ restauración nacionalista sienta plaza de adoctrinador de historia viva, esto es, sustancia de filosofía, moral estética y pedagogia política o civismo. Como se ve Rojas enfrenta una crisis de crecimiento de nuestra nacionalidad sofocada por el promíscuo cosmopolitismo y snobismo. Propone una terapéutica que exalta los valores vernaculares, partiendo de un íntimo conocimiento de nuestro pasado. Entrevé una reforma de la enseñanza con vistas sociales y culturales, para lo cual contempla el nuevo tramo que ha recorrido el país en materia de experiencia técnica e institucional. Rojas sugiere soluciones que involucran una crítica a los planes educacionales, si bien alcanza por elevación al desarraigado sentimiento colectivo. Echa mano al instrumental científico de su tiempo en armonía con la intuición del artista: modela la arcilla del alma infantil sin desdeñar el soplo de civismo. Rojas retoma los ideales americanos, cuyo logro no depende de los practicones de la politiquería electoralista ni de la burocracia cultural. Inicia así el diálogo con Sarmiento, artista whitmaniano de la política, la educación y la sociología que crean nuevos valores humanos y sociales a tono con el Nuevo Mundo. Rojas vuelve los ojos al apostolado de Sarmiento: imperativo de "educar al soberano" y preeminencia de nuestra tradición democrática. El discípulo no se podrá desprender a lo largo de su vida del abrazo dialéctico del maestro ni de sus premisas tentaculares. Rojas comienza su ascensión hacia la americanidad a través de la nacionalidad, aunque aquel libro no registra más que los primeros faldeos. Además, el autor comprobó con pena cómo el "chauvinismo" bastardeaba el sentido de su toque de atención.

\section{INDIGENISMO Y EXOTISMO}

A comienzos de este siglo Buenos Aires había dejado a sus espaldas el aire de "gran aldea" y se extasiaba ante su crecimiento vertiginoso. Apenas desembarcado el visitante europeo, extendía el certificado que lisonjeaba las ostensibles ínfulas de la ciudad cosmopolita. Las estadísticas, según Disraeli, constituyen la tercera forma de la mentira, pero el porteño, presa del temor al ridículo, apelaba a las cifras. Las consultaba como esos descreídos del tiempo que sólo confían en los boletines meteorológicos. 
Diarios, agentes de bolsa, rematadores, bancos, viajeros, todos proclamaban la presión barométrica de una ola de prosperidad y riqueza. Por supuesto, en el coro de loas al engrandecimiento argentino algunas voces desafinaban, bien entendido, por móviles distintos, no todos confesables. La mezcla de razas, la baraúnda de lenguas, cultos, usos y costumbres, habían debilitado el ascendiente de los núcleos tradicionales. Ciertos sectores del patriciado con miras reaccionarias, sentían nostalgias del poder que pronto pasaría a otros grupos. En vísperas del Centenario de la Revolución de Mayo la masa nativa, unida a la prole del aluvión inmigratorio, se orientaba a tientas hacia fuerzas políticas y dirigentes populares. Sus ideales representaban democráticamente los intereses de la mayoría. Veinte años después Rojas iba a volcar sus simpatías partidarias a dicho movimiento; pero por entonces permanecía en su atalaya especulativa, más cerca del aristocratismo intelectual de moda que del rumor de la calle. Férvido "profesor de idealismo", como otros escritores hispanoamericanos de su generación, preconizó el culto a las tradiciones del país, subestimando una de ellas, la tradición popular. Sin embargo, por aquellos años, los manes de Moreno y Sarmiento ambulaban de incógnito por las calles porteñas. Mezclados al turbión anónimo celebraban las fiestas del Centenario grande, no en el formalismo declamatorio, clato está, sino en su avatar del pasado vivo que empuja al presente. Asistían, apenas acompañados por escasos intelectuales, al alba de un nuevo ciclo histórico. Ricardo Rojas se adhirió a los actos conmemorativos del Centenario, publicando el libro El blasón de plata (I9ro). Leopoldo Lugones elevó en honor de la efemérides la mirra de cuatro obras: Piedras liminares, Odas seculares, Prometeo y Didáctica. Alberto Gerchunoff se consagró con Los gauchos judios, relatos de inmigrantes donde la raza perseguida alaba el arribo al Canaán entrerriano.

Rojas vuelve a enfrentarse en el citado libro con la sombra de Sarmiento y ensaya algunas fintas ideológicas. Encabeza el volumen, a modo de epígrafe, la inquietante pregunta que el autor de Conflictos y armonia de las razas lanzó a las futuras generaciones: "¿Argentinos? Desde cuándo y hasta dónde, bueno es darse cuenta de ello". Antes que designios doctrinarios, Rojas confiesa su anhelo de componer un producto de emocionada fe en el destino de su raza. Desde el prólogo vibra en forma explícita su solidaridad americana. Campea a lo largo del volumen la erudición histórica, marco dentro del cual el relato de la conquista, colonización e independencia asume acentos de epopeya. La clave de mitos y símbolos guía al autor que descifra el misterio de la "tierra indiana". 
Abundan felices páginas colmadas de primores literarios, retratos psicológicos, cuadros y paisajes cubiertos por la pátina con que el pasado transfigura la geografia, pero Blasón de plata interesa más por la tesis.

Como se sabe, Sarmiento propuso en Facundo la antinomia "civilización y barbarie", que fue luego repetida a troche y moche sin tener en cuenta la intención originaria. Cumplía el fin de espoleta polémica y "slogan" en la lucha contra la tiranía de Rosas. No cabe, pues, desglosarla del libro fundador de nuestra literatura, cuyo calculado carácter de panfleto es una de sus tantas originalidades. El autor lo admitió así varios lustros más tarde, aparte de que su intuitivo sentido de la realidad histórica, varia y fluyente, sobrepuja cualquier esquematismo. Dicha disyuntiva prestó servicios en un momento dado, extensivo, a las campañas contra el resurgimiento del caudillismo primitivo. Rojas sin embargo no comparte tal punto de vista. De ahí su tardía réplica a Sarmiento cuando la evolución del país había radiado aquella antinomia. En efecto, sesenta años después de lanzada la fórmula "civilización y barbarie", Rojas opone otra menos válida todavía: "Exotismo e indianismo". Envuelta en vaporoso atavío retórico, la tesis de Blasón de plata no podía pasar inadvertida a la curiosidad del Nuevo Mundo. Chocaba el ingrediente racista, exasperado como sostén de un nacionalismo político en pugna con el credo democrático del autor. Ese desplante antieuropeo, refractario a la tradición de la cultura greco-latina, carecía de eco incluso en pueblos hispanoamericanos de fuerte arraigo autóctono. Era un gesto de ardoroso idealismo indigenista sin raíces en la realidad histórica del indio contemporáneo. Lo más llamativo de tal exabrupto era la procedencia argentina donde la densidad social y cultural indígenas apenas cuenta, si se la compara con otros pueblos hermanos.

\section{ROJAS E INGENIEROS}

A raíz de Blasón de plata José Ingenieros publicó una carta abierta al autor en La Revista de América (julio de I9r3) que Francisco García Calderón dirigía en París. La epístola tiene una doble importancia por el tema en debate, de interés argentino y americano, y porque sitúa al remitente y al destinatario en el cuadro de los problemas de la época. Ingenieros refuta en términos fraternales la peligrosa tesis de su amigo, bajo la cual descubre un equívoco: la confusión del sentimiento de la patria con el de la tradición hispano-indígena. Previene a Rojas contra el fondo racista de su excluyente indianismo, así como el virtual nacionalismo po- 
lítico, a un paso de la xenofobia o susceptible, por su énfasis emocional, de dar pie a malentendidos. "¿Crees, por ventura, que los descendientes de los hispano-indígenas tendrán el monopolio del patriotismo?" - pregunta Ingenieros. Y agrega: "Los [argentinos] de la primera colonización conciben el nacionalismo como una conservación de sus monopolios de casta contra los de la segunda: defienden sus privilegios feudales, en el funcionarismo político y administrativo". Más adelante afirma su fe en el porvenir del país bajo la influencia latina y no anglosajona. Recordando el proyecto de Belgrano de coronar a un Inca, Ingenieros resume: "Tu credo representa la aspiración de una vieja Argentina feudal que se extingue; mi nacionalismo, el de una nueva Argentina que se va europeizando. Tú pones tu ideal donde Belgrano; yo donde Sarmiento".

Las proyecciones de esta cordial divergencia de temperamentos $y$ mentalidades tienen también una significación americana. Rojas, pese a sus sinceras reivindicaciones indigenistas y nacionalistas se mantuvo al margen de la Revolución Mexicana que afectaba a aquéllas y a la Reforma Universitaria, no obstante sus ideales de "americanidad". Defendía honestamente la autonomía espiritual de estos pueblos, no sin advertir hasta dónde la comprometía la servidumbre económica, aunque sin tomar partido públicamente. Cierta reticencia, ya que no insensibilidad ni falta de perspicacia políticas, neutralizaron en tal sentido su prestigiosa voz. La juventud de entonces, a quien Rojas se dirigía y que lo acataba como maestro, se privó de su lección de Próspero a su manera. Frente a su silencio desorientador, se destacó ante la juventud argentina y de los pueblos hermanos, el magisterio consecuente de Alfredo L. Palacios e Ingenieros, sin olvidar a Manuel Ugarte. Con motivo de la visita de José Vasconcelos a nuestro país, se le of reció un banquete en octubre de 1922. En aquella ocasión Ingenieros pronunció el resonante discurso-programa "Por la Unión-Latinoamericana". Al lado de ese pronunciamiento y otros análogos (el propio Vasconcelos hizo circular después el lema "criollismo contra monroísmo"), la americanidad de Rojas se desvaneció en un ansia noble e idealista, si bien desprovista de vigencia. El prestigioso autor de $E l$ profeta de la pampa, el 12 de octubre de 1942 disertó en la Universidad Nacional del Litoral precisamente sobre "Americanidad". Concretando alli sus ideales y tras distinguir la Americanidad del Panamericanismo, expresó: "Los pueblos menos capaces, al juntarse con los más capaces, quedarán sometidos a la superioridad de estos últimos, y entonces no hay ventajas en aislarse, ni la hay en murmurar contra los imperialismos". 


\section{ALgUNOS PRECURSORES ARGENTINOS DE IA DOCTRINA AMERICANA}

El régimen colonial monopolista y retardatario estaba a cargo de una burocracia indiferente cuando no hostil con respecto al nativo. Su mayor celo consistía en fiscalizar la obediencia de los súbditos al lejano monarca y remachar la censura para ahuyentar las ideas perturbadoras. Aparte, procuraba sacar ventajas personales del sistema de privilegio. Salvo contadas excepciones, como las de Hernandarias y el Virrey Vértiz, ni la miseria ni la ignorancia ni el progreso social preocupaban a las autoridades. Virreyes y magistrados hacían llevadero como podían el confinamiento en estas tierras desprovistas del imán del oro y la plata. Una de las compensaciones era el usufructo del contrabando, remotos orígenes de la secuela de prerrogativas, peculado y fraude cuyo pasivo se incorporó al país emancipado. Los gobiernos patrios se vieron obstruidos por las corruptelas de difícil desarraigo. Todos esos vicios del régimen colonial engendraron descontento y ansias de liberación. Rojas no los calla, si bien los atenúa su hispanofilia apologética, suerte de amnistía con efecto retroactivo de varios siglos. Naturalmente el juicio histórico, ajeno a los usos parlamentarios, no acepta interrupciones. La servidumbre común dio homogeneidad por la lógica de los hechos a la resistencia que se operó en los virreinatos más alejados. Estaban casi sin contacto entre sí debido a las enormes distancias y al atraso en los medios de comunicación, fuera del aislamiento deliberado con fines políticos para evitar los contagiosos conatos de rebeldía. Así la estacionaria y opresiva existencia colonial tuvo un común denominador que se tradujo luego en los rasgos cosanguíneos de la revolución americana. Sus protagonistas legaron multitud de programas, decretos, discursos, artículos insertos en el incipiente periodismo y hasta escorzos autobiográficos. Los conflictos particulares de cada país se recortan sobre el fondo de la exhausta vida virreinal y los efectos de su inercia niveladora. Sobre ese subsuelo histórico se asienta la estructura política, social y cultural de nuestros pueblos. $\mathrm{Y}$ allí se configura el substráctum de cualquier atisbo doctrinario con pretensiones de validez americana.

Como no podía ser de otra manera, Ricardo Rojas encontró la filosofía de la nacionalidad a modo de torsos diseminados en la obra de sus predecesores inmediatos. Conforme a la mentalidad de su época habian reelaborado la doctrina originaria y el autor de La argentinidad hizo lo propio. Pues bien, los actores principales de la emancipación argentina, así como los prohombres de la lucha contra la anarquía y la tiranía de Rosas, incluso los propulsores de la organización nacional, todos vibran 
con las visicitudes que se desarrollan en el ámbito del Nuevo Mundo. Mariano Moreno, tildado de "furibundo americano" por un maturrango, escribe: "El genio americano que ha inventado tantos recursos en un solo pueblo, obrará prodigios en toda América; y concentrados todos los poderes, cuyo interés debe conducir a un mismo fín, se presentará un Estado que libre de riesgos y temores podrá reglar una constitución que haga la felicidad del país y el honor de la humanidad". Juan José Castelli, en vísperas del pronunciamiento del 25 de mayo de i81o, lanza la fórmula expeditiva: "España ha caducado en su poder para con la América, y con ella las autoridades que son su emanación". Una vez estallada la revolución, la propaga por el interior del pais y cumple el primer tramo cuya acción proselitista continuarán otros emisarios a lo largo de este hemisferio. Todos nuestros próceres hablaron y actuaron con los ojos puestos en el pueblo americano. Este vocativo cobra en pocos hombres públicos tanta vehemencia como en Bernardo Monteagudo, sucesor de Moreno en Las Gaceta, secretario de San Martín en el Perú, luego ministro en Lima, des. pués agente revolucionario en Quito y Panamá y, en fin, colaborador de Bolivar en los preparativos para la instalación del Congreso continental. Con tal objeto escribió el famoso ensayo cuyo título compendia su categórico y ejecutivo ideario americanista: "Sobre la necesidad de una federación general entre los Estados hispanoamericanos y plan de su organización". La amenaza de la Santa Alianza enciende el verbo de aquel jacobino con ribetes byronianos. Poco más tarde epilogaba trágicamente en Lima su vida borrascosa. En cuanto a Rivadavia y sus aspiraciones a un "Ayacucho diplomático", Bartolomé Mitre midió la trascendencia americana del proyecto. Era un experimento dictado por un orden institucional, prematuro con respecto a la anarquía reinante, aunque demostrativo de su aleccionadora inspiración civil. Ricardo Rojas es por lo general ecuánime y mesurado en sus juicios, pero pierde el equilibrio frente a Rivadavia, a quien menoscaba para realzar a Gorriti.

Resultaría fatigosa, por lo extensa, la nómina de los precursores argentinos que echan las bases de la americanidad en el pensamiento y la acción. La generación de I837 articula el sueño de Bolívar dentro del fervor tomántico combinado con las exigencias del liberalismo político. Ella parte de la indagación de nuestra incipiente contextura democrática para conocer sobre el terreno las características y afinidades ciertas. De tal manera localiza el aire de familia que nos vincula a los pueblos salidos de la incubadora colonial. La emoción fraterna y la percepción neta de la realidad histórica se funden en el lenguaje lapidario de Esțeban Eche- 
verría, Domingo F. Sarmiento, Juan B. Alberdi, Bartolomé Mitre, Juan Ma. Gutiérrez. Nadie en adelante puede caer en divagaciones sobre el hecho americano sin falsearlo ni mucho menos ampararse en aquellos precursores. Rojas en la Historia de la literatura argentina estudió con entrañable perspicacia el credo filosófico, estético y político de Echeverría. Puso de manifiesto la claridad que fue definidora por excelencia del "principio democrático de la revolución americana", según repetía en sus apotegmas. El autor de El matadero acuñó en concisas fórmulas el repudio al régimen colonial, la fe en el pueblo y la dignificación de las masas, el apoyo a la organización social y a la libertad en beneficio de la justicia y la cultura popular. "Nos parece absurdo ser español en literatura y ameticano en política", argumentaba hace I20 años Echeverría, teórico del genuino nacionalismo literario, que le debe además creaciones inaugurales. Propugnó sin tregua la "emancipación del espíritu americano", uno de los capítulos centrales del Dogma socialista.

Acerca de la raigambre americana de Sarmiento, no es indispensable abundar aquí en mayores consideraciones. Pero es la piedra de toque alrededor de la cual gira Rojas y su amor a la autoctonía. Su eruptivo pensamiento, multiforme acción y profetismo telúrico franquearon hace un siglo nucstras fronteras. Desde Facundo (1845) hasta Conflictos y armonias de las razds (1883) forja la doctrina a medida que participa en la transformación del país de arriba abajo. Su genio visionario y a la vez pragmático es un hervidero de sugestiones, iniciativas, encontronazos con el conformismo del medio. Monta guardia contra el desquite de los instintos primarios en belicosa retirada. A la crítica demoledora de la herencia colonial y de sus brotes rebeldes, acopla la apertura de un cauce de veras democrático de ideas, costumbres, instituciones. Sarmiento personifica la encrucijada ideológica entre el destino nacional y continental frente a la influencia europea. El profeta de la pampa -visto por Rojasintrospecciona su delirio civilizador. En el último libro, escrito cinco años antes de su muerte, ataca el nudo gordiano: "¿Qué es América? ¿Qué somos los argentinos?" - -se pregunta. La respuesta se remonta a las fuentes de la historia del Nuevo Mundo, de donde arrancan los problemas troncales. Sus proposiciones afectan pues a todos los pueblos del mismo origen y por eso cada uno siente al "montonero de las lettas" como suyo. Sarmiento esgrime un interrogante crucial para la cultura argentina en cierne que repercute en el larvado orden americano. Sale al paso del sociólogo, del educador y del simple estudioso, ávido de mirar hacia adelante y atrás en demanda de rutas. Ricardo Rojas a semejanza de otros 
escritores de su generación, no pudo evitar el contrapunto con Sarmiento, rompeolas de pasión progresista e inteligencia en acecho del futuro.

Por su parte Alberdi ocupó los cuarenta años de expatriación en meditar desde el observatorio europeo sobre la suerte de su país, bien que dentro de la "magna patria" americana. Que ésta le preocupaba a fondo ya en la juventud, lo corrobora, entre otros trabajos, el anunciador Fragmento preliminar al estudio del Derecho (1837). Tras insistentes reflexiones sobre el tema, anota: "Nuestros padres nos dieron una independencia material; a nosotros nos toca la conquista de una forma de civilización propia, la conquista del genio Americano. Dos cadenas nos ataban a la Europa: una material que tronó; otra inteligente que vive aún". Y más adelante resume: " $\mathrm{La}$ inteligencia americana quiere también su Bolívar, su San Martín. La filosofía americana, la política americana, el arte americano, la sociabilidad americana son otros tantos mundos que tenemos por conquistar". Siete años después Alberdi se instaló en Santiago de Chile, donde presentó su tesis universitaria titulada Memoria sobre la conveniencia y objetos de un Congreso general americano (1844). Dicho proyecto de Congreso, al que Andrés Bello sumó su adhesión, perseguía el fin de resolver litigios civiles e internacionales en resguardo de la próspera convivencia en este hemisferio. Aparte del sólido renombre continental del constitucionalista, economista y sociólogo, el autor de Basés atrajo la atención de los círculos filosóficos por algunos sagaces atisbos cuyo interés continental subrayó Alejandro Korn. "Nuestra filosofía pues ha de salir de nuestras necesidades -escribía Alberdi en I842-. De aquí es que la filosofía americana debe ser esencialmente política y social en su objeto, ardiente y profética en sus instintos, sintética y orgánica en sus métodos, positiva y realista en sus procederes, republicana en su espíritu y destinos". Hoy por diversos caminos se inquiere un peculiar estilo de vida, de especulación y de arte, síntesis de la heterogeneidad étnica y de las fluidas clases sociales que reflejan su hibridez en nuestra cultura en cuarto creciente. Según Alberdi, la auténtica filosofía no sólo emergetá de nuestras necesidades, sino de la lucha para afianzar el goce de la libertad y el perfeccionamiento del orden social. Por eso "la abstracción pura, la metafísica en sí -aclara - no echará raíces en América".

En esta rápida reseña de nuestros escritores de la primera mitad del siglo $\mathrm{XIX}$, intérpretes de las aspiraciones continentales, merecen ser citados dos nombres señeros. Mitre, antes aludido, escribe sus monumentales historias de Belgrano y San Martín. Si bien sitúa a los protagonistas 
en el escenario nacional, centro de la acción originaria, sus sucesivos desplazamientos llevan el foco del relato a otros medios geográficos, políticos y culturales. Mitre narra la vida de Belgrano dentro del marco de la turbulencia post-revolucionatia, choque de intereses y pasiones de predominio entre Buenos Aires y las provincias. El precedente examen de la estructura económica y social de la Colonia reúne el diseño de conjunto, la riqueza de detalles y la penetración de juicio de las páginas definitivas. En la historia de San Martín alterna la multitud de perspectivas y el paralelo psicológico y moral de los héroes con una aguda caracterización de la independencia americana. En este último aspecto, en el escrupuloso investigador de la Colonia y en la intuición del biógrafo, profusamente documentada, Rojas encontró en Mitre pistas y pautas que facilitaron su acceso al conocimiento del pasado, sin perjuicio de otros atajos privativos. En lo tocante a Juan María Gutiérrez basta decir que logró la primera compilación continental con su libro América poética (I846). Experto exhumador y comentarista de crónicas coloniales, su curiosidad intelectual atravesó las fronteras del suelo nativo. Si el erudito, el crítico y el artista que coexistían en Gutiérrez se aplicaron al estudio de Ruiz de Alarcón, Sor Inés de la Cruz, Juan de Caviedes y otras figuras americanas, el albacea de Echeverría mereció la recíproca solidaridad de José Enrique Rodó, autor de un acabado estudio sobre su obra. También Gutiérrez -exégeta, historiador literario, americanista-- encauzó las disciplinas en las que más tarde se adentratía Ricardo Rojas, quien lo reconoció en la Historia de la literatura argentina, donde también dedica sendos capítulos a Echeverría, Sarmiento, Alberdi y Mitre.

Los pocos antecedentes recordados denotan con su lejana preexistencia el celo fraterno de los pensadores y artistas argentinos acerca de los pueblos de común origen hispánico. Desde los albores de nuestra nacionalidad los hombres de letras representativos fueron fieles al reclamo de los valores humanos en función de la tierra y las tradiciones. Legaron conforme al saber de su tiempo, conceptos claros, amplios y profundos. Pero tal prioridad está lejos de limitarse a servir de autohalago patriótico: supone un compromiso de acrecimiento para las generaciones actuales. $\mathrm{Ni}$ es sensato desandar el trecho recorrido ni desentenderse del impulso prospectivo que los ideales americanos imprimen al examen de conciencia argentino. Este último involucra a aquéllos si la introspección colectvia se impregna de sensibilidad histórica. Hoy los imperativos de justicia social y de cultura nacional (Alejandro Korn troqueló esta fórmula en I925) son más perentorios que cuando Ricardo Rojas imponía su nombre. Vale 
la pena pues contrastar el contenido de su "americanidad" con arreglo al modo de sentirla entonces y de concebirla ahora.

\section{LA "otra AmÉrica" y "EURINDiA"}

A menudo oímos hablar de la "otra América'. Unos señalan antagonismos y armonías entre los dos bloques -latino y sajón-; otros entre las tradiciones indígenas en pugna con la civilización criolla, depositaria de vestigios discriminativos todavía irreductibles. Germán Arciniegas traza un corte longitudinal y esboza un paralelismo étnico y cultural a dos bandas, cada una bajo la respectiva esfera de influencia oceánica: al Nuevo Mundo del Atlántico opone el flanco del Pacífico donde el coeficiente indígena adquiere una fuerte coloración reivindicatoria. En fin, algunos pensadores como el mexicano José Vasconcelos y el brasileño Gilberto Freyre razonan la preeminencia del mestizo, único tipo representativo en la llamada América latina, donde hay cerca de roo millones de indios y mestizos y 15 millones de negros. Ricardo Rojas, aunque no ha formulado con rigor sistemático su concepto de la americanidad, se aproxima sin duda a esta última tesitura. Por el predominio de la intuición emocional coincide con el racismo indigenista de Gabricla Mistral, aun cuando la vida trashumante de la autora de Tala le ha dado mayor longitud de onda. El recóndito patetismo de la excelsa chilena arranca con cargas de amor secretos ancestrales a la tierra madre. Sus salmos mixtos de conjuros, se propagan a la manera de un remezón andino, invocando deidades ocultas, desde Arauco hasta el suelo de los aztecas.

Ahora bien, por encima de los irredentismos raciales y de las involucradas exclusiones ideológicas, gana terreno un sentido distinto de la "otra América". Existe un modo diferente de concebir ese hemisferio ideal, no como una substancia de inconciliable impronta étnica, sino como una función urgida por el imperativo ético y la cohesión asimiladora. Dicha concepción se apoya menos en las ciencias naturales que en las modernas ciencias históricas y culturales, pues gravita sobre ella el dinámico llamado del futuro. Acuerdo fecundo de la inteligencia, voluntad y sentimiento, el vislumbre de la "otra América" pertenece al tiempo, es la que está aún por hacer. Extrae de las antinomias y flaquezas del pasado, las fuerzas morales y materiales que se requieren para plasmar el presentido Nuevo Mundo. La "otra América" aspira a colmar el nuevo continente de un nuevo contenido de valores humanos y sociales sin minorías usurpadoras ni privilegios de casta o fortuna. Cada generación tributaria de la 
filosofía y la ciencia contemporáneas, plasma la cuota de esa "otra América" a su imagen y semejanza, pero solidaria con la tensión colectiva. La "otra América" se nutre con los esfuerzos afines del pasado y se anticipa a los aportes del porvenir. A esa "otra América" - redivivo mito de la Atlántida rescatada - respondió la parábola de Rodó "el que vendrá".

Ricardo Rojas resulta difuso unas veces y otras reticente ante el planteo realista que exige el feudalismo crónico y la penetración económica, debido a la cual los pueblos subdesarrollados del Nuevo Mundo no pueden salir de la tutela opresiva. Profesor de idealismo, fiel a la tónica de su generación, habló a la juventud y le impartió generosos ideales democráticos. En tal sentido cooperó en la tarea de inculcar fe en el futuro. Toca ahora a los jóvenes traducir ese efusivo mensaje a un idioma acorde con el espíritu de los problemáticos tiempos actuales.

América presiente que su originalidad estriba en buscar un estilo de conocimiento que no se agote en el virtuosismo teorizante. Sus vigías intelectuales creen que el conocimiento crece y capta esencias profundas de la realidad americana a medida que se integra con la acción. Transformar la estructura económica y política, recalcitrante legado de la Colonia, equivale a imprimirle al espíritu energías creadoras y a manumitirlo de las abstracciones declamatorias. Por algo el revisionismo radical de Martínez Estrada tiene resonancia más allá de nuestras fronteras.

El hombre es agente y paciente, transforma el medio físico y moral a la vez que la justicia y demás valores sociales reciben la benéfica influencia de tales cambios. Acción política y contemplación estética se conjugan en Sarmiento, según Rojas lo ha dilucidado exhaustivamente en El profeta de la pampa. En la misma órbita actúan los arquitectos de la "magna patria" al decir de Pedro Henríquez Ureña, doctrinario y al par egregio exponente de ella. Sus nombres tutelares orientan a las generaciones en ascenso: Montalvo, Martí, Hostos, Varona, Rodó, Ingenieros, Mariátegui. Pensadores venidos más tarde enriquecen ese patrimonio continental con interpretaciones ceñidas a la índole y a las características nacionales. Alfonso Reyes, Antonio Caso, Juan Marinello, Germán Arciniegas, Picón Salas, Leopoldo Zea, Arturo Ardao y otros practican sondeos de gran calado en nuestra realidad histórica. Los estudios especializados son objeto de relevamientos panorámicos tan enjundiosos como el de Francisco Romero Sobre la filosofía de América y la antología prologada y anotada por Aníbal Sánchez Reulet. A propósito del ensayo Alberto Zum Felde abarca casi toda el área de la especulación en su medulosa obra Indice critico de la literatura hispano-americana. La simbiosis de la acción política 
y la contemplación estética apasiona de un extremo a otro del Nuevo Mundo, como ocurre con Martí, cuyo "activismo creador" analizó nuestro compatriota Víctor Massuh. Incluso entre los escritores jóvenes el tema promueve agitados debates como el que se prolonga alrededor de $\mathrm{H}$. A. Murena y El pecado original de América.

Dentro de ese cuadro de interpretaciones del destino americano, el autor de Eurindita ocupa un puesto aventajado no sólo por sus anticipos, sino por el anhelo vocacional que acredita medio siglo de prédica. Quizás la ambiciosa tentativa de su libro Eurindia se diluye en premisas y planteos generales a los que escapa la correlación de los problemas concretos así como la rica complejidad de las diversas regiones de América. Compárese los aproximativos lineamientos de Eurindia con la apretada trama metódica y la precisión valorativa de Pedro Henríquez Ureña en Historia de la cultura en la América Hispánica y el estudio gemelo Las corrientes literarias. Quizás también las reivindicaciones indigenistas de Rojas, no siempre apoyadas en fundamentos objetivos, hayan alentado sentimentalismos retrógrados y negaciones del progreso social en pugna con la ostensible devoción sarmientista del autor. Con todo, el afán de perseguir una síntesis dignifica las páginas de Eurindia, bosquejo de historia y estética, introducción al examen de los ideales de cultura en el Nuevo Mundo. Es una lástima que Eurrindid sea poco menos que un libro ignorado por los escritores jóvenes. Si lo leyeran, su curiosidad no saldría defraudada, aunque sólo fuera para juzgar con espíritu crítico la sensibilidad y las direcciones intelectuales que hace tres décadas tenían alguna vigencia. Si bien lo americano en Eurindia casi se circunscribe al desarrollo de la civilización argentina, constituye un complemento de la Historia de la literatura del mismo autor, quien de paso replica a los que impugnaron dicha obra. Los escritores jóvenes descubrirán en Eurindia un ensayo de tetralogía wagneriana, donde el determinismo del territorio, la raza, la tradición y la cultura engendra la "argentinidad" a través de cuatro actos o etapas: lo indigena, lo colonial, lo nacional y lo cosmopolita. Ni ese esquema ni mucho menos la equivalencia del fenómeno argentino con el mexicano son hoy sostenibles, pero ilustran sobre la reducción de la "americanidad" a la "argentinidad". Rojas transmitía la visión esotérica de ambas mediante un lenguaje de iniciado.

\section{LA DOBLE INFLUENCIA}

Rojas ha sido sensible en extremo a la crítica provocada por sus obras, pese a que muchas de ellas fueron escritas con designio polémico. Blanco 
alguna vez de ataques descomedidos, cuya queja razonable encontró eco solidario en Unamuno, tampoco se avenía al disentimiento en términos respetuosos. Llevado por sus firmes convicciones las sostenia públicamente sin teatos, pero hacía oídos sordos a las téplicas. Rehuía la controversia o guardaba un silencio altivo, no tan inexpugnable como lo suponía, pues siempre algún contertulio indiscreto dejaba filtrar el comentario de puertas adentro. Sus discípulos y amigos íntimos estaban en el secreto de la recatada y pudorosa decisión de absorber el castigo en letras de molde. Con todo su digna voluntad de silencio era susceptible de ser considerada por los demás como un desplante desdeñoso al derecho a la crítica. Muchos admiradores de Rojas lo juzgaban a veces precipitadamente y de oidas, atribuyéndole cierta suficiencia intelectual. Sea lo que fuese, esa impresión unida al retraimiento acentuado en los últimos lustros de su vida, le restó a su señera personalidad y voluminosa obra la influencia deseable. Desaparecido Lugones en 1938 , Rojas estaba llamado a ejercer en vastos círculos intelectuales, sociales y aún políticos el papel de director de conciencia, sobre todo antes, durante y después de la grave crisis que sufrió en el país la opinión pública. Ese voluntario eclipse de gravitación personal recrudeció a partir de su militancia partidaria a raíz de la revolución de Septiembre de r930. Durante su confinamiento en Ushuaia, junto con otros jefes del radicalismo, escribió y ordenó materiales para varios libros, pero la desproporcionada sanción obtuvo sus calculados efectos vejatorios. La dictadura se ensañó no tanto contra el ocasional dirigente del partido mayoritario y opositor como contra el conspícuo representante intelectual incorporado a la lucha cívica. El instinto oligárquico tolera sólo al escritor inofensivo, proclive a la connivencia con el usufructo del privilegio. Ricardo Rojas, teórico de la ameticanidad, padeció así en su patria los efectos del despotismo, mal endémico del Nuevo Mundo.

¿En qué medida la lección americanista de Rojas hizo prosélitos en el país? Contribuyó a suscitar vocaciones jóvenes en torno a la investigación sistemática del folklore. Por extensión irradió el interés alrededor del tema americano desde el punto de vista literario, plástico y musical. Su generoso fermento idealista cuajó en un reducido núcleo de escritores y artistas capacitados para comprender el mensaje de Eurindid. Mensaje viable dentro de una línea de iniciativas y sugestiones, sujetas a ulteriores desarrollos metódicamente concretos. En cambio la prédica de Rojas fomentó sin poder evitarlo el culto de un seudo arte americano, remedo y pastiche de un supuesto estilo incaico que es pura chafalonía de bazar. Nadie deploró 
el mal entendido más que Rojas cuyo prólogo a la edición de los Comentarios Reales del Inca Garcilaso, hecha en Buenos Aires, condensa su conocimiento fervoroso de la civilización del Cuzco. Los escritores de la generación del novecientos asistieron impasibles al contrapunto Indianismo versus Exotismo, debate promovido por Rojas con escasa audiencia. Para ellos, europeizantes y estetizantes en su mayoría, el dilema se disipaba, pues el indianismo les parecía un alarde de fantasía exótica. En cuanto a los escritores de la llamada promoción "martinfierrista" y grupos posteriores, sostenían programas estéticos demasiado innovadores para ocuparse de Eurindia y sus problemas. Además habían roto amarras a fuerza de beligerancia y humor con los poetas, novelistas y ensayistas de la "guardia vieja", vale decir, Lugones y Rojas a la cabeza. Si a los jóvenes les preocupaba el americanismo era el de nuevo cuño, Diego Rivera y Orozco, Azuela, Rómulo Gallegos, Güiraldes, Icaza, Neruda, Vallejo. De todas maneras, le corresponde a Rojas el mérito de haber agitado el debate en la Argentina alrededor de las corrientes del pensamiento y del arte americanos. Su empeño proselitista es tanto más válido cuanto que data de medio siglo atrás en que predominaba la tónica del modernismo cosmopolita, divorciado de la tierra, las tradiciones y la autoctonía.

Coriolano Alberdini, tan habitualmente parco en el elogio, pronunció un discurso al suceder a Rojas en el decanato de la Facultad de Filosofía y Letras (I924), donde entre otras cosas, dijo: "Podrá la crítica futura filtrar su obra, pero abrigo la profunda convicción de que Rojas ocupará en la historia de la cultura argentina una jerarquía comparable a la de Herder en la cultura germánica". Incumbe pues a los exégetas literarios e historiadores de las ideas la tarea de tamizar el pródigo y multiforme legado del autor de El profeta de la pampa. Esa revisión contribuirá a aquilatar el pensamiento de Ricardo Rojas y a ubicarlo a la luz del espíritu de su tiempo. Tiende además a discernir la permanencia de sus cuantiosos aportes a nuestra cultura.

Luis Emilio Soto, Sociedad Argentina de Escritores. 
